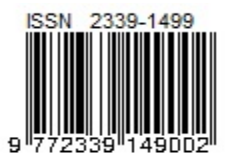

Paper ini telah direview dan dipublikasikan di Jurnal Rekayasa Sistem Industri

Volume 6 No.1 April 2017

http://journal.unpar.ac.id/index.php/jrsi/index

ISSN: 0216-1036 (print) \& ISSN 2339-1499 (online)

\title{
Pendekatan Fuzzy FMEA dalam Analisis Faktor Risiko Kecelakaan Kerja
}

\author{
Ronald Sukwadi ${ }^{1}$, Frederikus Wenehenubun ${ }^{2}$, Tarsina Wati Wenehenubun ${ }^{3}$ \\ ${ }^{1,3)}$ Fakultas Teknik, Jurusan Teknik Industri, Universitas Katolik Indonesia Atma Jaya \\ Jl. Jenderal Sudirman 51, Jakarta 12930 \\ Email: ronald.sukwadi@atmajaya.ac.id, watitarsina@gmail.com \\ 2) Fakultas Teknik, Jurusan Teknik Mesin, Universitas Katolik Indonesia Atma Jaya \\ Jl. Jenderal Sudirman 51, Jakarta 12930 \\ Email: frederikus.wen@atmajaya.ac.id
}

\begin{abstract}
This study aims to identify and analyze the risk factors of work accidents. Failure Mode and Effect Analysis (FMEA) and Fuzzy Logic approach are applied. The information obtained from the workers is expressed using fuzzy linguistics terms, and a FMEA method is proposed to determine the risk priority of failure modes. The results indicate that injuries caused when struck by an object are the highest risk factor of work accident $(F R P N=886)$. Some work improvements are suggested to reduce or eliminate the work risks.
\end{abstract}

Keywords: Risk factors, work accident, FMEA, Fuzzy

\begin{abstract}
Abstrak
Studi ini bertujuan untuk mengidentifikasi dan menganalisis faktor-faktor risiko kecelakaan kerja. Pendekatan FMEA dan logika fuzzy digunakan dalam penelitian ini. Informasi diperoleh dari pekerja yang dinyatakan dalam lingusitik fuzzy, dan metode FMEA digunakan untuk menentukan prioritas faktor risiko kegagalan. Hasil penelitian ini menunjukkan bahwa kecelakaan karena tertimpa benda memiliki faktor risiko tertinggi (dengan nilai FRPN=886). Beberapa perbaikan kerja disarankan untuk mengurangi atau menghilangkan risiko kerja tersebut.
\end{abstract}

Kata kunci: Faktor Risiko, Kecelakaan Kerja, FMEA, Fuzzy

\section{Pendahuluan}

Dengan semakin meningkatnya persaingan di bidang usaha maka perusahaan dituntut untuk meningkatkan daya saingnya agar mampu bertahan dalam industri yang bersangkutan dengan meningkatkan kualitas produk yang dihasilkan. Produk yang akan dihasilkan oleh suatu perusahaan, amat bergantung pada urutan proses produksi yang cermat dan tepat, yang tentu saja ditunjang oleh tersedianya tenaga kerja / operator yang terampil serta lingkungan kerja yang mendukung untuk peningkatan produktivitas pekerja.

Permasalahan yang sering ditemui di perusahaan yaitu kurangnya pemahaman operator atau pekerja tentang pentingnya keselematan kerja, lingkungan kerja yang tidak nyaman serta berat beban yang melebihi kemampuan operator yang berisiko terjadinya kecelakaan kerja yang akan berdampak pada produktivitas operator serta kualitas produk yang dihasilkan. Menurut Suma'mur (1989), Kelalaian dalam melakukan suatu pekerjaan dapat mengakibatkan kecelakaan. Kelalaian tersebut dapat disebabkan oleh kelelahan kerja yang dapat menyebabkan kecelakaan atau sakit akibat kerja. Kecelakaan akibat kerja adalah kecelakaan berhubung dengan hubungan kerja pada perusahaan. Hubungan kerja disini dapat berarti, bahwa kecelakaan terjadi dikarenakan oleh pekerjaan atau pada waktu melaksanakan pekerjaan. Dalam hal ini lingkungan kerja berkaitan erat dengan kenyamanan sehingga faktor ergonomik perlu dipertimbangkan dalam mendukung kenyaman operator saat bekerja serta memberikan pemahaman kepada operator tentang risiko yang bisa terjadi terutama perusahaan ini 
masih perusahaan baru beroperasi sehingga untuk mencegah terjadinya kecelakaan kerja yang akan berisiko terjadi.

Perkembangan angka kecelakaan kerja di Indonesia setiap tahunnya terus bertambah, menurut data BPJS pada tahun 2014, 69,59\% kecelakaan terjadi didalam perusahaan saat pekerja bertugas, $10,27 \%$ diluar perusahaan dan $20,15 \%$ pekerja mengalami kecelakaan lalu lintas dan berdasarkan data dari International Labour Organization (ILO), satu pekerja di dunia meninggal setiap 15 detik karena kecelakaan kerja atau penyakit akibat kerja. ILO juga mencatat, 153 pekerja di dunia mengalami kecelakaan kerja setiap 15 detik.

Berdasarkan data kecelakaan kerja pada PT. ATMI Cikarang, dalam 1 tahun beroperasi sudah terdapat 3 kecelakaan kerja berat diantaranya salah satu operator mengalami patah di beberapa jari tangannya karena tertekan oleh mesin stamping dan kecelakaan ringan lainnya. Oleh sebab itu untuk mencegah dan mengurangi angka kecelakaan kerja yang terjadi maka penelitian ini dibuat agar menambah wawasan operator serta perusahaan untuk lebih mengetahui risiko kecelakaan kerja yang bisa terjadi. Salah satu metode yang digunakan untuk mengetahui risiko kecelakaan kerja adalah metode FMEA (Failure Mode and Effects Analysis).

Menurut Leitch (1995), FMEA merupakan teknik analisis yang apabila dilakukan dengan tepat dan waktu yang tepat akan memberikan nilai yang besar dalam membantu proses pembuatan keputusan oleh engineer selama perancangan dan pengembangan. Jadi, dapat disimpulkan bahwa metode ini bisa digunakan untuk menganalisis risiko kecelakaan kerja karena memiliki beberapa kelebihan dibanding metode lain di antaranya hemat biaya, sistematis, dan penyelesaiannya tertuju pada potensial causes (penyebab yang potensial). Namun dengan berkembangnya ilmu pengetahuan dan teknologi, FMEA konvensional dianggap memiliki beberapa kelemahan sebagai alat pengawasan mutu perencanaan, misalnya pernyataan dalam FMEA sering subyektif dan kualitatif (Xu et al., 2002; Yeh \& Hsieh, 2007).

Oleh karena itu, untuk menutupi kelemahan metode FMEA tersebut maka perlu didukung oleh metode lain yaitu dengan menggunakan logika fuzzy. Logika ini terbukti telah sukses diintegrasikan dengan metode lain seperti AHP dan TOPSIS (Sukwadi et al, 2014). Menurut
Keskin (2009) menyatakan bahwa penelitian dengan menggunakan logika fuzzy akan memperoleh hasil yang lebih akurat dibandingkan dengan menggunakan metode FMEA tradisional. Fuzzy FMEA merupakan pengembangan dari metode FMEA yang memberikan fleksibilitas untuk menampung ketidakpastian akibat samarnya informasi yang dimiliki maupun unsur preferensi yang subjektif yang digunakan dalam penilaian terhadap mode kegagalan yang terjadi (Braglia et al., 2003). Dengan menambah konsep fuzzy pada algoritma FMEA memungkinkan data yang digunakan berupa data linguistik ataupun data numerik yang mana setiap data akan mempunyai nilai keanggotaan pada setiap atributnya. Adapun tujuan penelitian ini meliputi:

1. Mengidentifikasi faktor - faktor yang berisiko terjadinya kecelakaan kerja

2. Mengetahui faktor yang paling tinggi berisiko kecelakaan kerja dengan nilai RPN dan FRPN tertinggi

3. Memberikan usulan perbaikan untuk faktor risiko kecelakaan tertinggi

\subsection{Desain Penelitian}

\section{Metode Penelitian}

Objek dalam penelitian ini adalah PT.ATMI Cikarang, dengan batasan hanya di unit produksi stamping dengan jumlah responden sebanyak 20 orang dengan membagikan kuesioner. Responden yang digunakan merupakan operator mesin stamping. Selain itu juga dilakukan observasi terhadap proses permesianan (stamping).Periode waktu pengambilan data adalah 3 bulan.

\subsection{Alur Penelitian}

Langkah-langkah dalam penelitian ini digambarkan dengan alur metode penelitian pada Gambar 1.

\section{Hasil dan Pembahasan}

\subsection{Hasil perhitungan RPN dari Nilai Severity, Occurrence dan Detection}

Contoh perhitungan Risk Priority Number (RPN) seperti berikut: RPN = Severity (S) $x$ Occurrence $(0) \times$ Detectability (D)

Failure mode: Tertimpa Benda $\rightarrow$ RPN $=7.2 .5$ x $6.2 .5 \times 7.0=317.19$ 

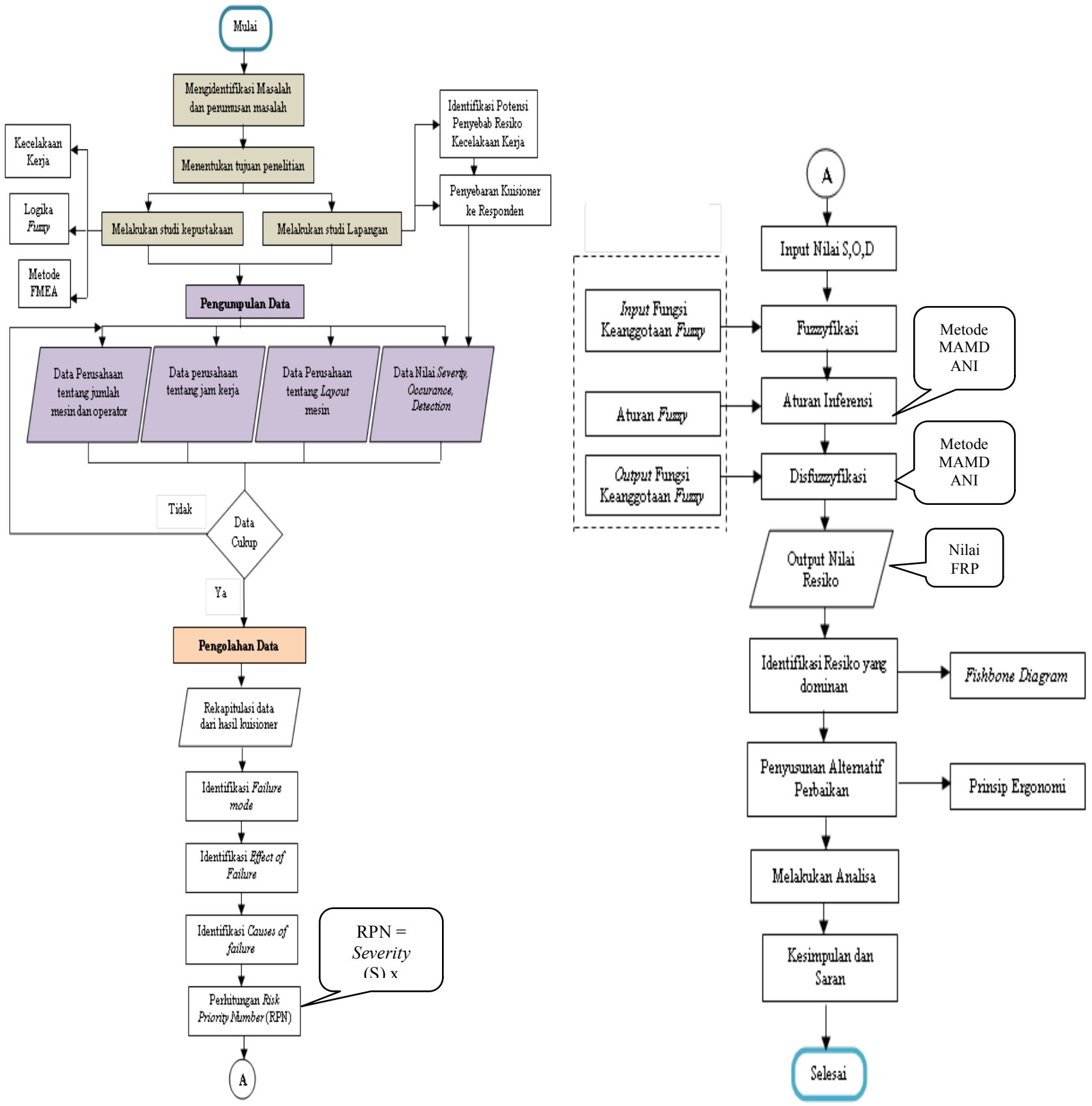

Gambar 1. Alur Metode Penelitian

Perhitungan Risk Priority Number (RPN) dengan nilai severity 7.25 menyatakan bahwa risiko kecelakaan tertimpa benda dapatmenyebabkan "cidera berat: menyebabkan cacat atau hilangnya fungsi tubuh", nilai Occurrence 6.25 menyatakan bahwa risiko kecelakaan kerja tertimpa benda terjadi pada tingkat rendah atau mungkin terjadi sewaktu - waktu, nilai Detection 7 menyatakan bahwa Control memiliki kemungkinan cukup tinggi

untuk mampu mendeteksi penyebab potensial kecelakaan. Rekap lengkapnya dapat dilihat pada Tabel 1. 
Tabel 1. Hasil Perhitungan RPN

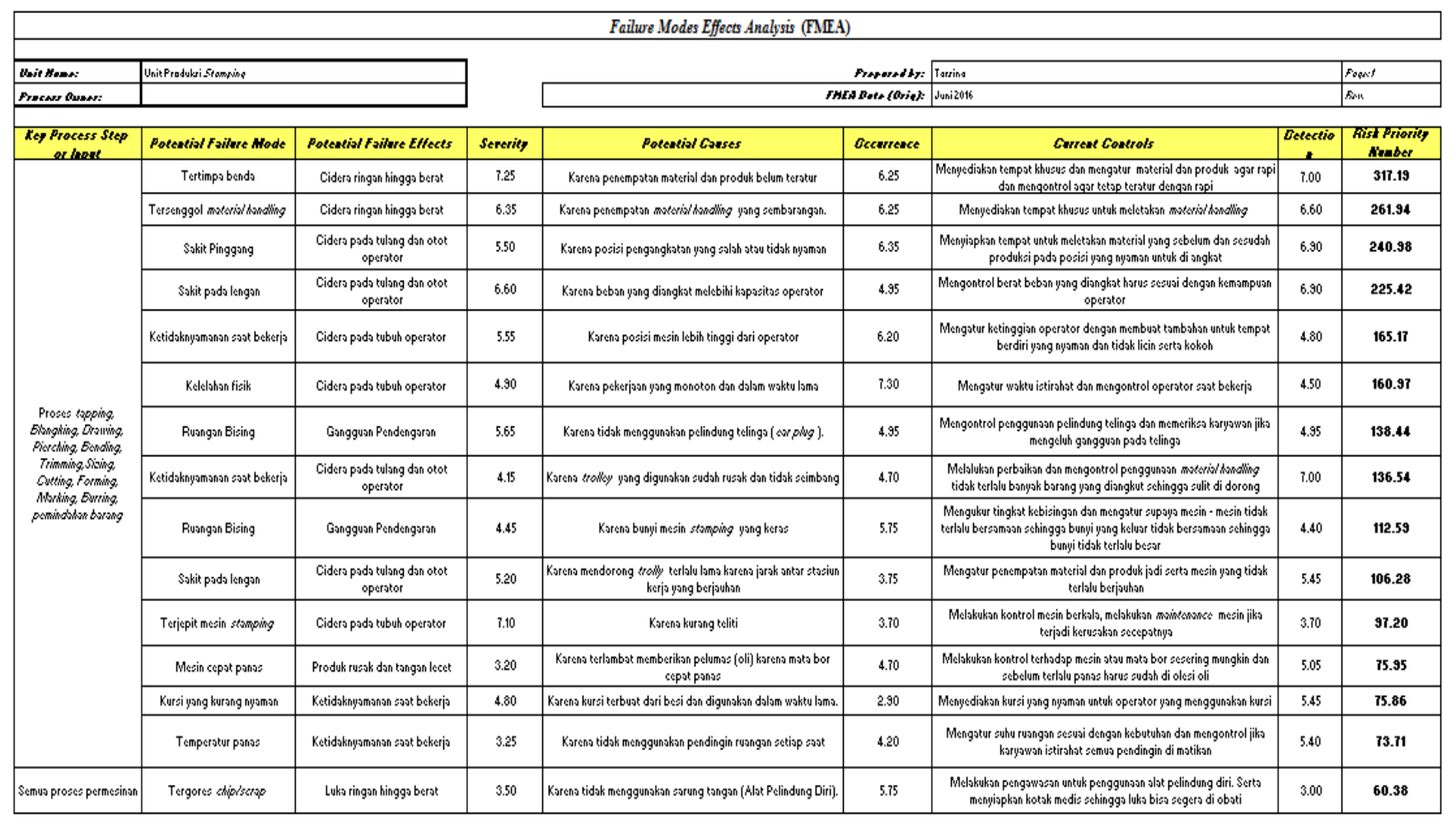

\subsection{Hasil perhitungan Fuzzy}

\section{a. Fuzzyfikasi}

Tabel 2 menyajikan proses fuzzyfikasi nilai Severity, Occurrence dan Detection

Tabel 2. Pengubahan Nilai Severity, Occurrence, dan Detection

\begin{tabular}{|c|c|c|c|}
\hline $\begin{array}{c}\text { Failure } \\
\text { Mode }\end{array}$ & \multicolumn{2}{|c|}{ Nilai } & Kategori \\
\hline \multirow{3}{*}{ F1 } & $\mathrm{S}$ & 7.25 & $\mathrm{H}$ \\
\cline { 2 - 4 } & $\mathrm{O}$ & 6.25 & $\mathrm{M}$ \\
\cline { 2 - 4 } & $\mathrm{D}$ & 7.00 & $\mathrm{H}$ \\
\hline \multirow{3}{*}{ F2 } & $\mathrm{S}$ & 6.35 & $\mathrm{M}$ \\
\cline { 2 - 4 } & $\mathrm{O}$ & 6.25 & $\mathrm{M}$ \\
\cline { 2 - 4 } & $\mathrm{D}$ & 6.60 & $\mathrm{M}$ \\
\hline \multirow{4}{*}{ F3 } & $\mathrm{S}$ & 5.50 & $\mathrm{M}$ \\
\cline { 2 - 4 } & $\mathrm{O}$ & 6.35 & $\mathrm{M}$ \\
\cline { 2 - 4 } & $\mathrm{D}$ & 6.85 & $\mathrm{M}$ \\
\hline \multirow{4}{*}{ F4 } & $\mathrm{S}$ & 6.60 & $\mathrm{M}$ \\
\cline { 2 - 4 } & $\mathrm{O}$ & 4.95 & $\mathrm{M}$ \\
\cline { 2 - 4 } & $\mathrm{D}$ & 6.90 & $\mathrm{M}$ \\
\hline \multirow{3}{*}{ F5 } & $\mathrm{S}$ & 5.55 & $\mathrm{M}$ \\
\cline { 2 - 4 } & $\mathrm{O}$ & 6.20 & $\mathrm{M}$ \\
\cline { 2 - 4 } & $\mathrm{D}$ & 4.80 & $\mathrm{M}$ \\
\hline \multirow{3}{*}{ F6 } & $\mathrm{S}$ & 4.90 & $\mathrm{M}$ \\
\cline { 2 - 4 } & $\mathrm{O}$ & 7.30 & $\mathrm{H}$ \\
\cline { 2 - 4 } & $\mathrm{D}$ & 4.50 & $\mathrm{M}$ \\
\hline \multirow{3}{*}{ F7 } & $\mathrm{S}$ & 5.65 & $\mathrm{M}$ \\
\cline { 2 - 4 } & $\mathrm{O}$ & 4.95 & $\mathrm{M}$ \\
\cline { 2 - 4 } & $\mathrm{D}$ & 4.95 & $\mathrm{M}$ \\
\hline \multirow{3}{*}{ F8 } & $\mathrm{S}$ & 4.15 & $\mathrm{M}$ \\
\cline { 2 - 4 } & $\mathrm{O}$ & 4.70 & $\mathrm{M}$ \\
\cline { 2 - 4 } & $\mathrm{D}$ & 7.00 & $\mathrm{H}$ \\
\hline
\end{tabular}

(bersambung)
Tabel 2. Pengubahan Nilai Severity, Occurrence, dan Detection (sambungan)

\begin{tabular}{|c|c|c|c|}
\hline $\begin{array}{c}\text { Failure } \\
\text { Mode }\end{array}$ & \multicolumn{2}{|c|}{ Nilai } & Kategori \\
\hline \multirow{3}{*}{ F9 } & $S$ & 4.45 & $\mathrm{M}$ \\
\hline & $\mathrm{O}$ & 5.75 & $\mathrm{M}$ \\
\hline & D & 4.40 & $M$ \\
\hline \multirow{3}{*}{ F10 } & $S$ & 5.20 & $M$ \\
\hline & $\mathrm{O}$ & 3.75 & $\mathrm{~L}$ \\
\hline & D & 5.45 & $M$ \\
\hline \multirow{3}{*}{ F11 } & $S$ & 7.10 & $\mathrm{H}$ \\
\hline & $\mathrm{O}$ & 3.70 & $\mathrm{~L}$ \\
\hline & D & 3.70 & $\mathrm{~L}$ \\
\hline \multirow{3}{*}{ F12 } & S & 3.20 & L \\
\hline & $\mathrm{O}$ & 4.70 & $M$ \\
\hline & D & 5.05 & $M$ \\
\hline \multirow{3}{*}{ F13 } & $S$ & 4.80 & $M$ \\
\hline & $\mathrm{O}$ & 2.90 & $\mathrm{~L}$ \\
\hline & D & 5.45 & $M$ \\
\hline \multirow{3}{*}{ F14 } & $S$ & 3.25 & $\mathrm{~L}$ \\
\hline & $\mathrm{O}$ & 4.20 & $M$ \\
\hline & $D$ & 5.40 & $\mathrm{M}$ \\
\hline \multirow{3}{*}{ F15 } & $S$ & 3.50 & $\mathrm{~L}$ \\
\hline & 0 & 5.75 & $M$ \\
\hline & D & 3.00 & $\mathrm{~L}$ \\
\hline
\end{tabular}

Berikut merupakan contoh perhitungan untuk failure mode (faktor risiko kecelakaan kerja) untuk masing - masing nilai Severity, Occurance, Detection.

$\mathbf{F 1}=\mathbf{S}: 7.25(\mathrm{H}) ; \mathbf{O}: 6.25(\mathrm{M}) ; \quad \mathbf{D}: 7.00$ (H)

Fungsi keanggotaan untuk himpunan $\mathrm{S}, \mathrm{O}$ dan $\mathrm{D}$ pada variable $\mathrm{F} 1$ : 
$\mu_{\mathrm{S}}[7.25]=\left\{\begin{array}{cc}(9-7.25) /(9-2.5) ; 2.5 \leq 7.25 \leq \\ 0 ; \quad 7.25 \geq 9\end{array}\right.$

$\mu_{\mathrm{S}}(7.25)=(\mathrm{x}-\mathrm{a}) /(\mathrm{b}-\mathrm{a})=(9-7,25) /(9-$ $2.25)=0,269$

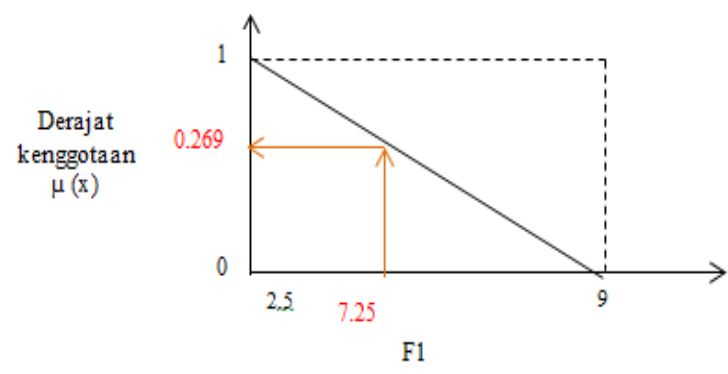

Gambar 2. Kurva Himpunan Fuzzy : Severity untuk Failure mode 1

Hasil perhitungan untuk nilai Severity, Occurrence dan Detection untuk masing masing failure mode (faktor kecelakaan kerja) dapat dilihat pada Tabel 3.

Tabel 3. Rekapitulasi Himpunan Keanggotaan Fuzzy pada faktor Severity, Occurrence dan Detection

\begin{tabular}{|c|c|c|c|c|c|}
\hline Failure & \multicolumn{2}{|c|}{ Nilai } & a & b & $\begin{array}{c}\text { Derajat } \\
\text { Keanggota }\end{array}$ \\
\hline \multirow{3}{*}{$\mathrm{F} 1$} & $\mathrm{~S}$ & 7.25 & 2.5 & 9 & 0.269 \\
\hline & $\mathrm{O}$ & 6.25 & 2.5 & 9 & 0.577 \\
\hline & D & 7.00 & 2.5 & 9 & 0.308 \\
\hline \multirow{3}{*}{$\mathrm{F} 2$} & $S$ & 6.35 & 2.5 & 9 & 0.592 \\
\hline & $\mathrm{O}$ & 6.25 & 2.5 & 9 & 0.577 \\
\hline & $D$ & 6.60 & 2.5 & 9 & 0.369 \\
\hline \multirow{3}{*}{ F3 } & $S$ & 5.50 & 2.5 & 7.5 & 0.600 \\
\hline & $\mathrm{O}$ & 6.35 & 2.5 & 7.5 & 0.770 \\
\hline & D & 6.85 & 2.5 & 7.5 & 0.130 \\
\hline \multirow{3}{*}{ F4 } & $\mathrm{S}$ & 6.60 & 2.5 & 7.5 & 0.180 \\
\hline & $\mathrm{O}$ & 4.95 & 2.5 & 7.5 & 0.490 \\
\hline & $D$ & 6.90 & 2.5 & 7.5 & 0.120 \\
\hline \multirow{3}{*}{ F5 } & $\mathrm{S}$ & 5.55 & 2.5 & 7.5 & 0.610 \\
\hline & $\mathrm{O}$ & 6.20 & 2.5 & 7.5 & 0.740 \\
\hline & D & 4.80 & 2.5 & 7.5 & 0.460 \\
\hline \multirow{3}{*}{ F6 } & $S$ & 4.90 & 2.5 & 7.5 & 0.480 \\
\hline & $\mathrm{O}$ & 7.30 & 6 & 9 & 0.567 \\
\hline & D & 4.50 & 2.5 & 7.5 & 0.400 \\
\hline \multirow{3}{*}{$\mathrm{F} 7$} & $S$ & 5.65 & 2.5 & 7.5 & 0.630 \\
\hline & $\mathrm{O}$ & 4.95 & 2.5 & 7.5 & 0.490 \\
\hline & $D$ & 4.95 & 2.5 & 7.5 & 0.490 \\
\hline \multirow{3}{*}{ F8 } & $S$ & 4.15 & 2.5 & 7.5 & 0.330 \\
\hline & $\mathrm{O}$ & 4.70 & 2.5 & 7.5 & 0.440 \\
\hline & $D$ & 7.00 & 2.5 & 9 & 0.308 \\
\hline
\end{tabular}

Tabel 3. Rekapitulasi Himpunan Keanggotaan Fuzzy pada faktor Severity, Occurrence dan Detection (sambungan)

\begin{tabular}{|c|c|c|c|c|c|}
\hline $\begin{array}{c}\text { Failure } \\
\text { Mode }\end{array}$ & \multicolumn{2}{|c|}{ Nilai } & a & b & $\begin{array}{c}\text { Derajat } \\
\text { Keangqotaan }\end{array}$ \\
\hline \multirow{3}{*}{ F9 } & $\mathrm{S}$ & 4.45 & 2.5 & 7.5 & 0.390 \\
\hline & $\mathrm{O}$ & 5.75 & 2.5 & 7.5 & 0.650 \\
\hline & $\mathrm{D}$ & 4.40 & 2.5 & 7.5 & 0.380 \\
\hline \multirow{3}{*}{ F10 } & $S$ & 5.20 & 2.5 & 7.5 & 0.540 \\
\hline & $\mathrm{O}$ & 3.75 & 1 & 7.5 & 0.577 \\
\hline & $\mathrm{D}$ & 5.45 & 2.5 & 7.5 & 0.590 \\
\hline \multirow{3}{*}{ F11 } & $\mathrm{S}$ & 7.10 & 2.5 & 9 & 0.708 \\
\hline & 0 & 3.70 & 1 & 7.5 & 0.415 \\
\hline & D & 3.70 & 1 & 7.5 & 0.415 \\
\hline \multirow{3}{*}{ F12 } & $S$ & 3.20 & 1 & 7.5 & 0.338 \\
\hline & $\mathrm{O}$ & 4.70 & 2.5 & 7.5 & 0.440 \\
\hline & D & 5.05 & 2.5 & 7.5 & 0.510 \\
\hline \multirow{3}{*}{ F13 } & $S$ & 4.80 & 2.5 & 7.5 & 0.460 \\
\hline & $\mathrm{O}$ & 2.90 & 1 & 7.5 & 0.292 \\
\hline & D & 5.45 & 2.5 & 7.5 & 0.590 \\
\hline \multirow{3}{*}{ F14 } & $S$ & 3.25 & 1 & 7.5 & 0.346 \\
\hline & $\mathrm{O}$ & 4.20 & 2.5 & 7.5 & 0.340 \\
\hline & $\mathrm{D}$ & 5.40 & 2.5 & 7.5 & 0.580 \\
\hline \multirow{3}{*}{ F15 } & $S$ & 3.50 & 1 & 7.5 & 0.385 \\
\hline & $\mathrm{O}$ & 5.75 & 2.5 & 7.5 & 0.650 \\
\hline & D & 3.00 & 1 & 7.5 & 0.308 \\
\hline
\end{tabular}

\section{b. Inferensi Fuzzy}

Untuk failure mode (faktor risiko kecelakaan kerja) untuk 15 variabel mempuanya 15 rule seperti berikut:

$\mathrm{R} 1$ : If (Severity is $\mathrm{H}$ ) and (Occurrence is $\mathrm{M}$ ) and (Detection is $\mathrm{H}$ ) then (FRPN is $\mathrm{VH})$

$\mathrm{R} 2$ : If (Severity is $M$ ) and (Occurrence is $M$ ) and (Detection is $\mathrm{M})$ then (FRPN is $\mathrm{H}$ )

R3 : If (Severity is M) and (Occurrence is M) and (Detection is $\mathrm{M})$ then (FRPN is $\mathrm{H}$ )

R4 : If (Severity is M) and (Occurrence is M) and (Detection is $\mathrm{M})$ then (FRPN is $\mathrm{H}$ )

R5 : If (Severity is M) and (Occurrence is M) and (Detection is $\mathrm{M})$ then (FRPN is $\mathrm{H}$ )

R6 : If (Severity is M) and (Occurrence is $H$ ) and (Detection is $\mathrm{M})$ then (FRPN is $\mathrm{H}$ )

R7: If (Severity is M) and (Occurrence is $M$ ) and (Detection is $\mathrm{M})$ then (FRPN is $\mathrm{H}$ )

R8 : If (Severity is M) and (Occurrence is M) and (Detection is $\mathrm{H})$ then (FRPN is $\mathrm{H})$

R9 : If (Severity is M) and (Occurrence is M) and (Detection is $\mathrm{M})$ then (FRPN is $\mathrm{H}$ )

R10: If (Severity is M) and (Occurrence is L) and (Detection is $\mathrm{M})$ then (FRPN is $\mathrm{M}-\mathrm{H})$

R11: If (Severity is $H$ ) and (Occurrence is $L$ ) and (Detection is $\mathrm{L})$ then (FRPN is $\mathrm{H}-\mathrm{VH})$

$\mathrm{R} 12$ : If (Severity is $\mathrm{L}$ ) and (Occurrence is $\mathrm{M}$ ) and (Detection is $\mathrm{M})$ then (FRPN is $\mathrm{M})$

R13: If (Severity is M) and (Occurrence is $L$ ) and (Detection is $\mathrm{M})$ then (FRPN is $\mathrm{M}-\mathrm{H})$

R14: If (Severity is L) and (Occurrence is M) and (Detection is $\mathrm{M}$ ) then (FRPN is $\mathrm{M}$ ) 
R15 : If (Severity is $L$ ) and (Occurrence is $M$ ) and (Detection is $\mathrm{L}$ ) then (FRPN is $\mathrm{L}-\mathrm{M}$ )

Setelah memperoleh 15 rule kemudian dengan menggunakan metode Mamdani untuk melakukan inferensi sistem fuzzy. Inferensi sistem fuzzy dengan menggunakan metode Max-Min yang merupakan salah satu metode dalam metode mamdani.

\section{+ Aplikasi fungsi implikasi:}

Rule 1 : If (Severity is $\mathrm{H}(7,25)$ ) and (Occurrence is $M(6,25)$ ) and (Detection is $\mathrm{H}(7,00))$ then (FRPN is VH )

$\mu_{\mathrm{S}}=0,269$

$\mu_{\mathrm{O}}=0,577$

$\mu_{\mathrm{D}}=0,308$

a-predikat ${ }_{1}=$

$=\mu_{\mathrm{S}} \mathbf{H} \cap \mu_{\mathrm{O}} \mathbf{M} \cap \mu_{\mathrm{D}} \mathbf{H}$

$=\min \left(\mu_{\mathrm{S}} \mathbf{H}(7,25), \mu_{\mathrm{O}} \mathbf{M}(6.25), \mu_{\mathrm{D}} \mathbf{H}(7)\right)$

$=\min (0.269 ; 0,577 ; 0,308)=\mathbf{0 , 2 6 9}$
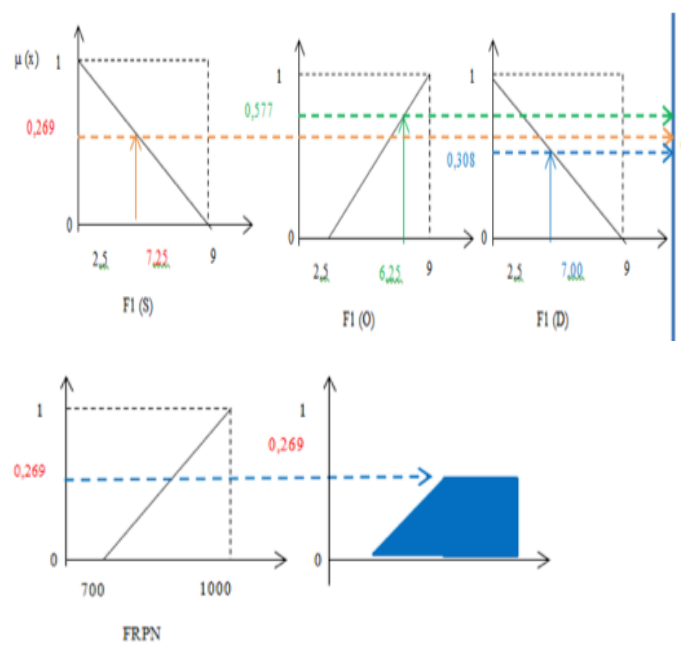

Gambar 3. Aplikasi fungsi implikasi untuk R1

\section{c. Komposisi antar aturan}

Dari hasil aplikasi fungsi implikasi dari tiap aturan, digunkan metode max untuk melakukan komposisi antar semua aturan

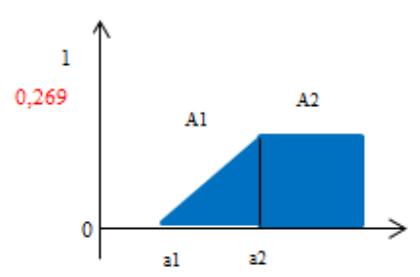

Gambar 4. Aplikasi fungsi implikasi untuk R1
Pada Gambar 4, daerah hasil dibagi menjadi 2 bagian, yaitu A1 dan A2. Sekarang kita cari nilai a1 dan a2.

$(\mathrm{a} 1-700) / 800=0 \quad ; \mathrm{a} 1=700$

$(\mathrm{a} 2-700) / 800=0,269 ; \mathrm{a} 2=915,2$

Dengan demikian, fungsi keanggotaan untuk hasil komposisi ini adalah:

$\mu[\mathrm{z}]=\left\{\begin{array}{cc}0 ; \quad z \leq 700 \\ (z-700) / 800 ; \\ 0,269 ; \quad z \geq 915,2\end{array} \quad 700 \leq\right.$ $z \leq 915,2$

\section{d. Penegasan (defuzzyfikasi)}

Metode penegasan yang digunakan adalah metode centroid.

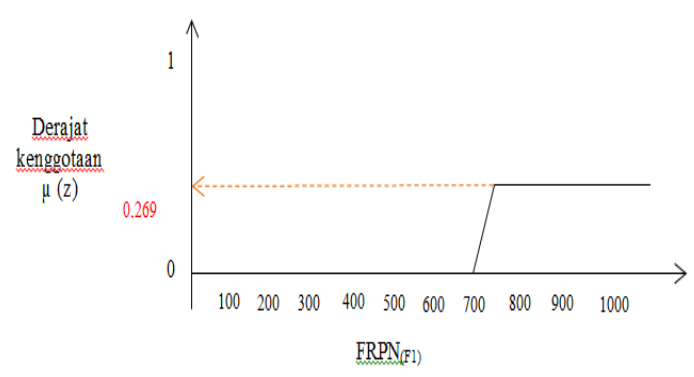

Gambar 5. Daerah Hasil Komposisi (F1)

Dari Gambar 5, dapat dikatakan bahwa daerah hasil komposisi untuk F1 berkisar antara 700 1000.

FRPN $=$

$\frac{((0+100+200+300+400+500+600) * 0) x(700+900+1000+1000) * 0,269}{0,269+0,269+0,269+0,269}=$ $\frac{968,40}{1,077}=\mathbf{8 9 9}$

Dari hasil perhitungan FRPN untuk failure mode 1 yaitu tertimpa benda diperoleh nilai FRPN sebesar 899. Hasil perhitungan nilai FRPN secara manual untuk semua failure mode dapat dilihat pada Tabel 4 .

\subsection{Identifikasi Faktor Risiko Kecelakaan Dominan}

Pada tahap ini dilakukan identifikasi faktor risiko yang dominan atau yang memiliki nilai FRPN tertinggi untuk mengetahui penyebab dari faktor kecelakaan tertinggi dengan menggunakan fishbone diagram. Hasil rank (peringkat) untuk 5 peringkat teratas selain diperoleh dari hasil perhitungan serta presentase nilai FRPN dapat dilihat pada Tabel 5. Faktor risiko kecelakaan kerja yang dominan dipengaruhi oleh beberapa faktor 
Tabel 4. Hasil Perhitungan Nilai FRPN manual dan software Matlab

\begin{tabular}{|c|c|c|c|c|c|c|c|c|c|c|c|c|c|}
\hline $\begin{array}{c}\text { Failure } \\
\text { Mode }\end{array}$ & Potential Causes & \multicolumn{2}{|c|}{ Nilai } & \multicolumn{2}{|c|}{ Kategori } & Kurva & $\mathbf{a}$ & b & \begin{tabular}{|c|} 
Derajat \\
Keanggo \\
\end{tabular} & $\begin{array}{c}\alpha- \\
\text { predik }\end{array}$ & $\begin{array}{c}\text { FRPN } \\
\text { Manual }\end{array}$ & $\begin{array}{c}\text { FRPN } \\
\text { (software }\end{array}$ & Rank \\
\hline \multirow{3}{*}{$\begin{array}{c}\text { Tertimpa } \\
\text { benda }\end{array}$} & \multirow{3}{*}{$\begin{array}{c}\text { Karena penempatan } \\
\text { material dan produk belum } \\
\text { teratur }\end{array}$} & s & 7.25 & $\mathrm{H}$ & \multirow{3}{*}{ VH } & Turun & 2.5 & 9 & 0.269 & \multirow{3}{*}{0.269} & \multirow{3}{*}{899} & \multirow{3}{*}{886} & \multirow{3}{*}{1} \\
\hline & & 0 & 6.25 & $\mathrm{M}$ & & \begin{tabular}{|l|} 
Naik \\
\end{tabular} & 2.5 & 9 & 0.577 & & & & \\
\hline & & $\mathrm{D}$ & 7.00 & $\mathrm{H}$ & & Turun & 2.5 & 9 & 0.308 & & & & \\
\hline \multirow{3}{*}{$\begin{array}{l}\text { Tersenggol } \\
\text { material } \\
\text { handling }\end{array}$} & \multirow{3}{*}{$\begin{array}{c}\text { Karena penempatan } \\
\text { material handling yang } \\
\text { sembarangan. }\end{array}$} & $\mathrm{s}$ & 6.35 & $\mathrm{M}$ & \multirow{3}{*}{$\mathrm{H}$} & Naik & 2.5 & 9 & 0.592 & \multirow{3}{*}{0.369} & \multirow{3}{*}{533} & \multirow{3}{*}{540} & \multirow{3}{*}{5} \\
\hline & & 0 & 6.25 & $\mathrm{M}$ & & \begin{tabular}{|l|} 
Naik \\
\end{tabular} & 2.5 & 9 & 0.577 & & & & \\
\hline & & D & 6.60 & $\mathrm{M}$ & & Turun & 2.5 & 9 & 0.369 & & & & \\
\hline \multirow{3}{*}{$\begin{array}{c}\text { Sakit } \\
\text { Pinggang }\end{array}$} & \multirow{3}{*}{$\begin{array}{c}\text { Karena posisi } \\
\text { pengangkatan yang salah } \\
\text { atav tidak nyaman }\end{array}$} & $\mathrm{s}$ & 5.50 & $\mathrm{M}$ & \multirow{3}{*}{$\mathrm{H}$} & \begin{tabular}{|l|} 
Naik \\
\end{tabular} & 2.5 & 7.5 & 0.600 & & & & \\
\hline & & 0 & 6.35 & $\mathrm{M}$ & & Naik & 2.5 & 7.5 & 0.770 & 0.130 & 533 & 542 & 4 \\
\hline & & $\mathrm{D}$ & 6.85 & $\mathrm{M}$ & & Turon & 2.5 & 7.5 & 0.130 & & & & \\
\hline & Karena beban yang & $\mathrm{s}$ & 6.60 & $\bar{M}$ & & Turun & 2.5 & 7.5 & 0.180 & & & & \\
\hline Sakit pada & diangkat melebihi kapasitas & $\mathrm{O}$ & 4.95 & $\mathrm{M}$ & $\mathrm{H}$ & \begin{tabular}{|l|} 
Naik \\
\end{tabular} & 2.5 & 7.5 & 0.490 & 0.120 & 533 & 543 & 3 \\
\hline & operator & $\mathrm{D}$ & 6.90 & $\mathrm{M}$ & & Turun & 2.5 & 7.5 & 0.120 & & & & \\
\hline Ketidaknyam & & $\mathrm{s}$ & 5.55 & $\mathrm{M}$ & & Naik & 2.5 & 7.5 & 0.610 & & & & \\
\hline anan saat & Karena posisi mesin lebih & 0 & 6.20 & $\mathrm{M}$ & $\mathrm{H}$ & Naik & 2.5 & 7.5 & 0.740 & 0.460 & 533 & 534 & 7 \\
\hline bekerja & & $\mathrm{D}$ & 4.80 & $\mathrm{M}$ & & Naik & 2.5 & 7.5 & 0.460 & & & & \\
\hline & Karena pekerjaan yang & $\mathrm{s}$ & 4.90 & $\mathrm{M}$ & & Naik & 2.5 & 7.5 & 0.480 & & & & \\
\hline $\begin{array}{l}\text { Kelelahan } \\
\text { figit. }\end{array}$ & monoton dan dalam waktv & $\mathrm{O}$ & 7.30 & $\mathrm{H}$ & $\mathrm{H}$ & \begin{tabular}{|l|} 
Turun \\
\end{tabular} & 6 & 9 & 0.567 & 0.400 & 533 & 534 & 8 \\
\hline & & $\mathrm{D}$ & 4.50 & $\mathrm{M}$ & & Naik & 2.5 & 7.5 & 0.400 & & & & \\
\hline & Karena tidak menggunakan & $\mathrm{s}$ & 5.65 & $\mathrm{M}$ & & Naik & 2.5 & 7.5 & 0.630 & & & & \\
\hline Ruangan & pelindung telinga (ear & 0 & 4.95 & $\mathrm{M}$ & $\mathrm{H}$ & Naik & 2.5 & 7.5 & 0.490 & 0.490 & 533 & 534 & 9 \\
\hline & plug). & $\mathrm{D}$ & 4.95 & $\mathrm{M}$ & & Naik & 2.5 & 7.5 & 0.490 & & & & \\
\hline Ketidaknyam & Karena trolley yang & $\mathrm{s}$ & 4.15 & $\mathrm{M}$ & & Naik & 2.5 & 7.5 & 0.330 & & & & \\
\hline anan saat & digunakan svdah rusak dan & 0 & 4.70 & $\mathrm{M}$ & $\mathrm{H}$ & \begin{tabular}{|l|} 
Naik \\
\end{tabular} & 2.5 & 7.5 & 0.440 & 0.308 & 533 & 535 & 6 \\
\hline bekerja & tidak seimbang & $\mathrm{D}$ & 7.00 & $\mathrm{H}$ & & Turon & 2.5 & 9 & 0.308 & & & & \\
\hline & & $\mathrm{S}$ & 4.45 & $\mathrm{M}$ & & Naik & 2.5 & 7.5 & 0.390 & & & & \\
\hline Ruangan & Karena bunyi mesin & 0 & 5.75 & $\mathrm{M}$ & $\mathrm{H}$ & Naik & 2.5 & 7.5 & 0.650 & 0.380 & 533 & 533 & 10 \\
\hline & & $\mathrm{D}$ & 4.40 & $\mathrm{M}$ & & Naik & 2.5 & 7.5 & 0.380 & & & & \\
\hline & Karena mendorong trolly & $\mathrm{s}$ & 5.20 & $\mathrm{M}$ & & Naik & 2.5 & 7.5 & 0.540 & & & & \\
\hline Sakit pada & terlalu lama karena jarak & 0 & 3.75 & $\mathrm{~L}$ & M-H & \begin{tabular}{|l|} 
Turun \\
\end{tabular} & 1 & 7.5 & 0.577 & 0.540 & 400 & 483 & 11 \\
\hline & $\begin{array}{c}\text { antar stasiun kerja yang } \\
\text { beriawhan }\end{array}$ & $\mathrm{D}$ & 5.45 & $\mathrm{M}$ & & Naik & 2.5 & 7.5 & 0.590 & & & & \\
\hline Terjepit & & $\mathrm{s}$ & 7.10 & $\mathrm{H}$ & & Turun & 2.5 & 9 & 0.708 & & & & \\
\hline mesin & Karena kurang teliti & 0 & 3.70 & $\mathrm{~L}$ & $\mathrm{H}-\mathrm{VH}$ & Turun & 1 & 7.5 & 0.415 & 0.415 & 700 & 700 & 2 \\
\hline stamping & & $\mathrm{D}$ & 3.70 & $\mathrm{~L}$ & & \begin{tabular}{|l|} 
Turun \\
\end{tabular} & 1 & 7.5 & 0.415 & & & & \\
\hline & Karena terlambat & $\mathrm{s}$ & 3.20 & $\mathrm{~L}$ & & Turun & 1 & 7.5 & 0.338 & & & & \\
\hline Mesin cepat & memberikan pelumas (oli) & 0 & 4.70 & $\mathrm{M}$ & M & Naik & 2.5 & 7.5 & 0.440 & 0.338 & 300 & 300 & 13 \\
\hline & $\begin{array}{c}\text { karena mata bor cepat } \\
\end{array}$ & $\mathrm{D}$ & 5.05 & $\mathrm{M}$ & & \begin{tabular}{|l|} 
Naik \\
\end{tabular} & 2.5 & 7.5 & 0.510 & & & & \\
\hline Kursi yang & Karena kursi terbuat dari & $\mathrm{s}$ & 4.80 & $\mathrm{M}$ & & \begin{tabular}{|l|} 
Naik \\
\end{tabular} & 2.5 & 7.5 & 0.460 & & & & \\
\hline korang & besi dan digunakan dalam & $\mathrm{O}$ & 2.90 & $\mathrm{~L}$ & M-H & \begin{tabular}{|l|} 
Naik \\
\end{tabular} & 1 & 7.5 & 0.292 & 0.292 & 400 & 469 & 12 \\
\hline nyaman & waktu lama. & $\mathrm{D}$ & 5.45 & $\mathrm{M}$ & & Naik & 2.5 & 7.5 & 0.590 & & & & \\
\hline & & $\mathrm{s}$ & 3.25 & $\mathrm{~L}$ & & Turun & 1 & 7.5 & 0.346 & & & & \\
\hline Temperatur & pendingin ruangan setiap & $\mathrm{O}$ & 4.20 & $\mathrm{M}$ & M & Naik & 2.5 & 7.5 & 0.340 & 0.340 & 300 & 300 & 14 \\
\hline & saat & $\mathrm{D}$ & 5.40 & $\mathrm{M}$ & & Naik & 2.5 & 7.5 & 0.580 & & & & \\
\hline & Karena tidak menggunakan & $\mathrm{s}$ & 3.50 & $\mathrm{~L}$ & & Turon & 1 & 7.5 & 0.385 & & & & \\
\hline Tergores & sarung tangan (Alat & $\mathrm{O}$ & 5.75 & $\mathrm{M}$ & L-M & \begin{tabular}{|l|} 
Naik \\
\end{tabular} & 2.5 & 7.5 & 0.650 & 0.308 & 208 & 210 & 15 \\
\hline chip/scrap & Pelindung Diri). & $\mathrm{D}$ & 3.00 & $\mathrm{~L}$ & & Naik & 1 & 7.5 & 0.308 & & & & \\
\hline
\end{tabular}

yaitu, manusia, material, mesin, lingkungan dan metode. Gambar 6 menyajikan contoh fishbone diagram dari 5 failure mode tertinggi.

\section{Kesimpulan}

Berdasarkan hasil analisis data maka dapat disimpulkan hal-hal sebagai berikut:

a) Dari hasil identifikasi faktor risiko kecelakaan kerja maka diperoleh 15 faktor risiko kecelakaan kerja yaitu risiko tertimpa benda, tertimpa material handling, posisi pengangkatan kurang nyaman, beban yang diangkat melebihi kapasitas operator, mesin lebih tinggi dari operator, posisi berdiri dalam waktu lama, bising, material andling tidak nyaman, terjepit mesin, mesin cepat panas, kursi kurang nyaman, temperatur panas, banyak chip.

b) Dari hasil perhitungan dengan metode FMEA konvensional diperoleh yang memiliki nilai RPN tertinggi adalah failure mode 1 (F1) atau faktor risiko kecelakaan karena tertimpa benda yang dapat mengakibatkan cedera pada tubuh operator dengan nilai sebesar 317.19 sebagai peringkat 1 .

c) Dari hasil perhitungan dengan logika fuzzy untuk perhitungan manual yang memiliki nilai FRPN terbesar adalah failure mode 1 (F1) sebesar 899 sedangkan nilai FRPN dengan menggunakan software MATLAB memiliki hasil yang sama dimana yang 


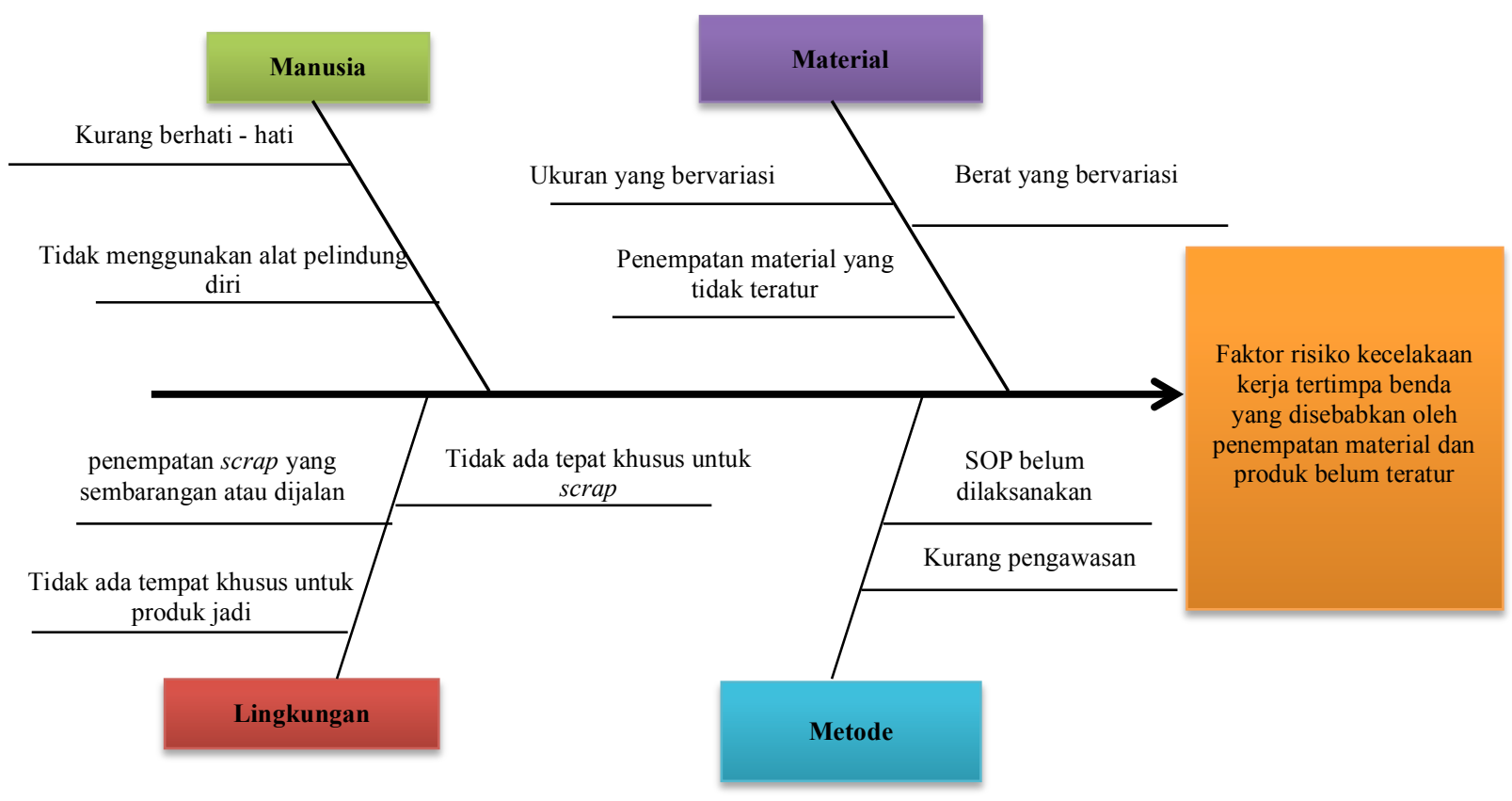

Gambar 6. Fishbone Diagram untuk faktor risiko kecelakaan kerja (F1)

merupakan faktor risiko kecelakaan tertinggi adalah failure mode 1 (F1) yaitu sebesar 886. Walaupun kedua nilai sedikit berbeda namun tidak mengubah prioritas atau peringkat.

d) Dari hasil identifikasi faktor risiko kecelakaan kerja dominan yaitu tertimpa benda maka dilakukan beberapa perbaikan kerja seperti:

- Pelatihan K3 untuk operator. Pelatihan ini dilakukan secara berkala.

- Perancangan rak. Perancangan ini mempertimbangkan tingkat keselamatan pekerja dan perlu peralatan khusus untuk menjangkau benda dengan ketinggian tertentu.

- Pembuatan standar operasional prosedur/SOP dan poster K3. SOP bertujuan untuk memandu operator agar bekerja secara benar, aman dan nyaman.

Metode 5R (Rapi, Resik, Rawat, Rajin, Ringkas) dapat diterapkan untuk melakukan penataan dan pembersihan tempat kerja. Bila tempat kerja tertata rapi, bersih dan tertib, maka kemudahan bekerja operator dapat diciptakan dan dengan demikian efisiensi, produktifitas, kualitas dan keselamatan kerja dapat lebih mudah dicapai.
Tabel 5. Nilai FRPN 5 Peringkat Atas

\begin{tabular}{|c|c|c|c|c|}
\hline Rank & & $\begin{array}{c}\text { Failure } \\
\text { Mode }\end{array}$ & Effect & Causes \\
\hline 1 & $\mathrm{~F}$ & $\begin{array}{c}\text { Tertimpa } \\
\text { benda }\end{array}$ & $\begin{array}{c}\text { Cidera } \\
\text { ringan } \\
\text { hingga } \\
\text { berat }\end{array}$ & $\begin{array}{c}\text { Karena } \\
\text { penempatan } \\
\text { material dan } \\
\text { produk belum } \\
\text { teratur }\end{array}$ \\
\hline 2 & 1 & $\begin{array}{c}\text { Terjepit } \\
\text { mesin } \\
\text { stamping }\end{array}$ & $\begin{array}{c}\text { Cidera } \\
\text { pada } \\
\text { tubuh } \\
\text { operator }\end{array}$ & $\begin{array}{c}\text { Karena kurang } \\
\text { teliti }\end{array}$ \\
\hline 3 & $\mathrm{~F}$ & $\begin{array}{c}\text { Beban } \\
\text { yang } \\
\text { diangkat }\end{array}$ & $\begin{array}{c}\text { Cidera } \\
\text { pada } \\
\text { tubuh } \\
\text { operator }\end{array}$ & $\begin{array}{c}\text { Karena beban } \\
\text { yang diangkat } \\
\text { melebihi } \\
\text { kapasitas } \\
\text { operator }\end{array}$ \\
\hline 4 & $\mathrm{~F}$ & $\begin{array}{c}\text { Posisi } \\
\text { pengangk } \\
\text { atan }\end{array}$ & $\begin{array}{c}\text { Cidera } \\
\text { pada } \\
\text { tubuh } \\
\text { operator }\end{array}$ & $\begin{array}{c}\text { Karena posisi } \\
\text { pengangkatan } \\
\text { yang salah atau } \\
\text { tidak nyaman }\end{array}$ \\
\hline 5 & $\begin{array}{c}\mathrm{F} \\
2\end{array}$ & $\begin{array}{c}\text { Tertimpa } \\
\text { material } \\
\text { handling }\end{array}$ & $\begin{array}{c}\text { Cidera } \\
\text { ringan } \\
\text { hingga } \\
\text { berat }\end{array}$ & $\begin{array}{c}\text { Karena } \\
\text { penempatan } \\
\text { material } \\
\text { handling yang } \\
\text { sembarangan. }\end{array}$ \\
\hline
\end{tabular}




\section{Daftar Pustaka}

Braglia, M., Frosolini, M., \& Montanari, R. (2003). Fuzzy criticality assessment model for failure modes and effects analysis. International Journal of Quality \& Reliability Management, Vol. 20 (4), 503 - 524

Keskin, G.A., \& Ozkan, C. (2009). An alternative evaluation of FMEA: Fuzzy Art Algorithm. International Journal of Quality and Reliability Engineering, Vol. 25(6), 647661

Leitch, R.D. (1995). Reliability Analysis for Engineering An Introduction. New York: Oxford University Press Inc.

Sukwadi, R., Yang, C.C., \& Benny. (2014). Integrasi fuzzy AHP-TOPSIS dalam evaluasi kualitas layanan elektronik rumah sakit, Jurnal Teknik Industri: Jurnal Keilmuan dan Aplikasi Teknik Industri, Vol.16(1), 25-34.

Suma'mur. (1989). Keselamatan Kerja dan Pencegahan Kecelakaan. Jakarta: PT. Gunung Agung.

Xu, K., Tang, L.C., Xie, M., Ho, S.L., \& Zhu, M.L. (2002). Fuzzy assessment of FMEA for engine system. Reliability Engineering and System Safety, Vol.75, 17-29.

Yeh, R.H., \& Hsieh, M.H. (2007). Fuzzy assessment of FMEA for a sewage plant. Journal of the Chinese Institute of Industrial Engineers, Vol. 24, 505-512. 
(halaman ini dibiarkan kosong) 